\title{
Plastic surgery of nail folds combined with Arkada's method in patient with ingrown nail - case report
}

\section{Plastyka wałów paznokciowych połączona z metodą Arkady u pacjenta z wrastającym paznokciem - opis przypadku}

\author{
Tomasz Trochanowski1 ${ }^{1,3}$, Dariusz Kotlęga ${ }^{1,2}{ }^{\Perp}$, Monika Gołąb-Janowska² \\ ${ }^{1}$ Głogowski Szpital Powiatowy, Oddział Neurologii i Leczenia Udarów Mózgu, ul. Kościuszki 15, 67-200 Głogów \\ District Hospital, Department of Neurology and Stroke Treatment \\ 2 Pomorski Uniwersytet Medyczny w Szczecinie, Katedra i Klinika Neurologii, ul. Unii Lubelskiej 1, 71-252 Szczecin \\ Pomeranian Medical University in Szczecin, Department of Neurology \\ ${ }^{3}$ Źródlana Medyczne Centrum, ul. Źródlana 80, 65-734 Zielona Góra \\ Źródlana Medical Center \\ $\bowtie$ dkotlega@poczta.onet.pl
}

\begin{abstract}
Introduction: Ingrown nail (onychocryptosis) is a common condition in podiatric and surgical practices. It is usually chronic, recurrent, and affects every-day quality of life. Treatment can be divided into conservative and surgical methods and should be initiated by the former methods and followed by the latter if need be.

Case report: The report describes the case of a patient with an ingrown toenail, who suffered from recurrent bouts of
\end{abstract}

inflammation which were cured conservatively. The periods of relief were short-lasting, and thus he underwent two types of treatment simultaneously - surgical excision of the nail folds combined with Arkada's method. This treatment achieved two goals - withdrawal of all symptoms and a good aesthetic effect. No recurrences were reported.

Keywords: ingrown nail; unguis incarnates; onychocryptosis; Arkada's method; toenail folds.

\begin{abstract}
ABSTRAKT
Wstęp: Wrastający paznokieć (onychocryptosis) jest częstym schorzeniem w praktyce podologicznej i chirurgicznej. Zwykle przebiega w sposób przewlekły, nawracający i obniża jakość codziennego życia. Wyróżnia się dwa rodzaje leczenia - zachowawcze, stosowane początkowo, i zabiegowe, wykorzystywane w późniejszym okresie.

Opis przypadku: Doniesienie opisuje przypadek pacjenta z wrastającym paznokciem palucha. Obecne był nawracające
\end{abstract}

stany zapalne, które leczono zachowawczo. Okresy poprawy były krótkie, w związku z czym pacjent poddany został leczeniu poprzez zastosowanie dwóch metod jednocześnie - chirurgicznego wycięcia wałów paznokciowych połączonego z metodą Arkady. Takie leczenie pozwoliło na osiągnięcie dwóch celów - ustąpienia wszystkich objawów i dolegliwości oraz dobrego efektu estetycznego. Nie odnotowano nawrotów schorzenia. Słowa kluczowe: wrastający paznokieć; unguis incarnatus; onychocryptosis; metoda Arkady; wały paznokciowe.

\section{INTRODUCTION}

Ingrown nails are a very common ailment, which can cause undesirable aesthetic and physical symptoms. Their pathogenesis is related to the presence of a spike or unequal edge of the nail which perforates the epidermis of the nail fold, causing chronic pain and inflammation $[1,2,3]$. The problem of ingrown toenails is widespread in both surgical and podiatric practices. Onychocryptosis occurs most often in the hallux $[1,4,5]$. The reasons for the appearance of this ailment are the following: incorrect nail cutting, hyperhydrosis, compression of the nail folds on the nail plate due to trauma or inappropriately fitting footwear, genetic predisposition, and other nail diseases such as onychomycosis $[1,4,6]$. The initial signs and symptoms include inconvenience and pain $[1,7]$. Usually the penetration of the spike or part of the damaged nail into the tissues progresses, leading to increased intensity and duration of pain and inflammation in the surrounding area. Subsequently the toe becomes swollen, reddened, tensed, and painful $[1,2,7]$.

Nowadays, ingrown nails are treated by many methods, which can be generally divided into conservative and surgical $[3,5,7]$. The first category contains such procedures as smoothing the edge of the nail, removing the spike, putting on nail braces, or performing the treatment by Arkada's method. There are various types of nail braces, which could be classified regarding the material which they are built of and the way of attaching to nail plate. Surgical methods include distinct procedures such as partial or complete avulsion of the nail plate with or without excision of the nail folds $[1,8]$. During surgical treatment, destruction of the matrix is usually performed with the use of surgical instruments or phenolisation (i.e. chemical intervention) $[4,7,9,10,11]$. However, surgical excision of nail folds could be performed with complete conservation of the matrix, nail bed, and nail plate $[6,12,13]$. In this article is 
presented a method which fulfills these criteria and also combines both conservative and surgical methods of treatment.

We present the case of a patient who underwent both types of treatment simultaneously: surgical excision of nail folds combined by Arkada's method (also called “Arkada's plastic surgery"). There have been limited descriptions of such treatment in the literature.

\section{CASE REPORT}

A 19-year-old male patient had been suffering from ingrown toenails on both big toes for 5 years. There was a family history of ingrown nails, his father and sister reporting the same problem. The patient's big toes were characterized by extremely enlarged nail folds (Fig. 1). He suffered from recurring inflammation that was cured conservatively. The periods of relief were short-lasting. Therefore, the decision to introduce plastic surgery of the folds combined with Arkada's method was made.

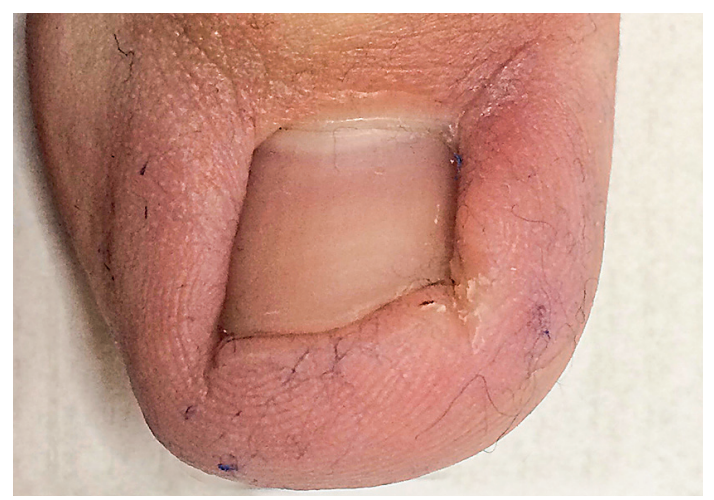

FIGURE 1. The ingrown nail before treatment

At the beginning, the treatment with Arkada's method was performed with Arkada's cube, where the toe was set to carry out the treatment (Fig. 2). When the toe was completely immobilized, special tools were used to push away the enlarged nail folds and enable exposure of the whole nail plate. Then all the losses of nail plate were filled and the outer surface of the nail plate was covered with acrylic resin, which finally enabled the recovery of the original shape of the nail. In that way, the anatomical conditions between the nail plate and the adjacent soft tissues changed. Subsequently, the patient underwent excision of the nail folds. This invasive treatment was performed under local anaesthesia and controlled ischemia. The latter helped to make apparent the nail and its edge, allowing checking of its completeness again, which is important for further recovery. Cutting and sewing were performed according to the strict rules in order to preserve the structure of the toe when healed (Fig. 3). The first dressing was removed after first 3 days and the next ones were changed by the patient himself every 2 days until the final removal of stitches after 14 days. During the next follow-up visit, the nail was shortened and the covering acrylic resin was removed completely. For the total period of follow-up, lasting 16 months, no recurrence was observed. The final effect is presented in Figure 4.

\section{DISCUSSION}

We present here a patient who was successfully treated with a novel method involving the combination of plastic surgery and Arkada's method. The most commonly used scale to assess the severity of such disorders is the Zaias scale (range: 0-3) [1,14]. The presented patient was recognized as a stage $2 / 3$, which corresponds to significant severity of symptoms; however, during the operation day, inflammatory conditions were backed out.

Initially, all patients should be treated with conservative methods. However, ingrown nails relapse frequently after conservative treatment and therefore offer no long-term relief. In such cases, subsequent surgical treatment is necessary [1]. According to some authors, surgical treatment of ingrown nails is more effective compared to conservative methods, in terms of limiting possible recurrences [7]. In cases of patients with deformed nails, especially after earlier surgical procedures, the condition is usually accompanied by chronic inflammatory process. Such patients are qualified for surgical treatment immediately. Patients who reach stage 3 according to the Zaias scale need surgical treatment of their ingrown nails. Since the year 1929, when Winograd's method was introduced, which

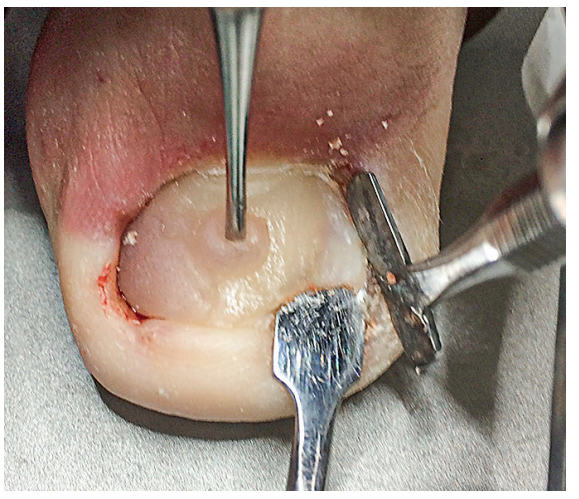

FIGURE 2. The ingrown nail during Arkada's method treatment

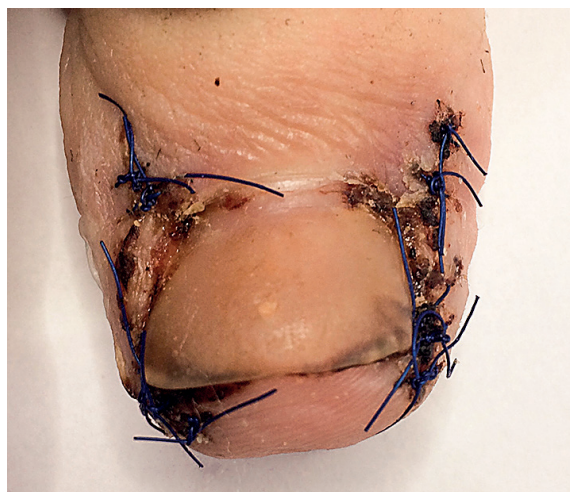

FIGURE 3. The sutures put into the big toe directly after the operation

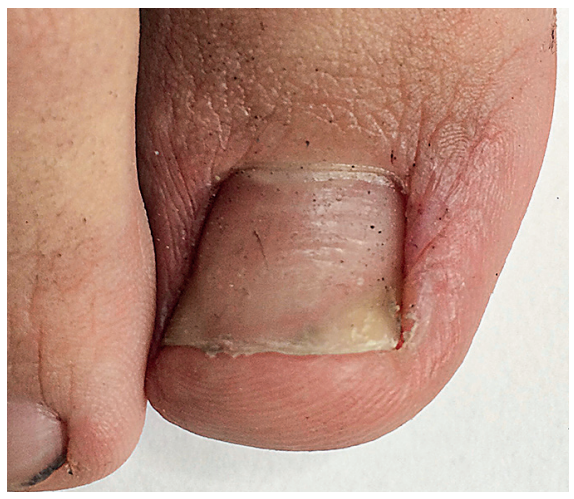

FIGURE 4. The nail after treatment completion 
consisted of partial avulsion of the nail combined with the adjacent nail fold, nail bed and nail matrix, several other methods have been used $[1,12,15]$. In 1950, Frost modified Winograd's procedure by changing the incision method [1]. All these methods are effective, however recurrences may occur $[3,6]$. The risk of recurrence is related to inadequate excision of the matrix, which causes the recurrence due to renewed growth of spicules. These surgical methods are also connected with irreversible lesioning of the nail plate, nail bed or nail folds, which usually leads to poor aesthetic effect $[1,6,12,15,16]$. The first described procedure which included the complete preservation of the nail matrix and nail plate was Vandenbos' procedure, described by Vandenbos and Bowers in 1959 [13, 16, $17,18]$. During this surgical treatment, the appropriate parts of the nail folds were excised and wounds were left to heal by secondary intention. In 2008, Noël described a similar procedure; however, the wound was closed with sutures $[6,16]$. Also Ince et al. described that wedge excision of soft tissue without affecting the nail itself lead to a lower complication rate [12]. All these procedures did not include any completion of the impaired nail plate.

In this report, the presented method of treatment of ingrown toenails is called "Arkada's plastic surgery", which is the excision of nail folds combined with Arkada's method. This is a novel technique of treatment that seems to be superior to other methods because of the fact that the nail plate is completely preserved and all possible nail losses, which usually occur during the preceding inflammatory process, are complemented in the course of Arkada's method treatment. The recreated nail plate with its original shape enables the physician to set the correct surgical incision lines in order to excise the exact demanded amount of soft tissue. Furthermore, the nail, after performing Arkada's method, is protected by the covering acrylic resin during the surgery and the process of healing is also not derailed. The corrected nail plate constantly maintains its shape and some stiffness. All these benefits decrease the possibility of potential recurrence.

The choice of a suitable method for the treatment of ingrown nails depends on the severity of the ailment and the experience level of the therapist; however, it should be taken into account that ingrown nails have a high degree of recurrence when treated inappropriately. Usually patients who were treated with Arkada's plastic surgery achieve complete recovery 2-3 weeks after the procedure, which provides a satisfactory result for both patient and physician. Such treatment leads to complete recovery in patients that had been suffering from ingrown nails for many years. It resolves the chronic inflammation, pain, and co-infections. Attention is also paid to the aesthetic value of the presented therapy, which is very high. Arkada's plastic surgery is a good alternative to other more popular methods in podiatric and surgical practices.

\section{REFERENCES}

1. Lorimer D, French G, O'Donnell M, Burrow JG, Wall B, editors. Neale's disorders of the foot. 7th ed. Edinburgh: Elsevier; 2006. p. 77-566.

2. Sano H, Oki K, Sogawa H, Ogawa R. The stainless steel wire-based method of Sogawa effectively corrects severe ingrown nails. Plast Reconstr Surg Glob Open 2016;4(8):e846.

3. Chitgopeker P, Johnson-Jahangir H. Chronic, severe onychocryptosis successfully treated with nail tube splinting in a 13-year-old girl with multiple prior failed matricectomies. Dermatol Online J 2016;22(6). pii: 13030/qt6cw147f0.

4. Heidelbaugh JJ, Lee H. Management of the ingrown toenail. Am Fam Physician 2009;79(4):303-8.

5. Correa J, Magliano J, Agorio C, Bazzano C. Super U technique for ingrown nails. Actas Dermosifiliogr 2017;108(5):438-44.

6. Noël B. Surgical treatment of ingrown toenail without matricectomy. Dermatol Surg 2008;34(1):79-83.

7. Eekhof JA, Van Wijk B, Knuistingh Neven A, van der Wouden JC. Interventions for ingrowing toenails. Cochrane Database Syst Rev 2012;(4):CD001541.

8. Huang JZ, Zhang YJ, Ma X, Wang X, Zhang C, Chen L. Comparison of wedge resection (Winograd procedure) and wedge resection plus complete nail plate avulsion in the treatment of ingrown toenails. J Foot Ankle Surg 2016;54(3):395-8.

9. Di Chiacchio N, Di Chiacchio NG. Best way to treat an ingrown toenail. Dermatol Clin 2015;33(2):277-82.

10. Terzi E, Guvenc U, Tursen B, Tursen U, Kaya TI. The effectiveness of matrix cauterization with bichloracetic acid in the treatment of ingrown toenails. Dermatol Surg 2017;43(5):728-33.

11. Romero-Pérez D, Betlloch-Mas I, Encabo-Durán B. Onychocryptosis: a longterm retrospective and comparative follow-up study of surgical and phenol chemical matricectomy in 520 procedures. Int J Dermatol 2017;56(2): 221-4.

12. Ince B, Dadaci M, Bilgen F, Yarar S. Comparison between knot and Winograd techniques on ingrown nail treatment. Acta Orthop Traumatol Turc 2015;49(5):539-43.

13. Livingston $\mathrm{MH}$, Coriolano $\mathrm{K}$, Jones SA. Nonrandomized assessment of ingrown toenails treated with excision of skinfold rather than toenail (NAILTEST): An observational study of the Vandenbos procedure. J Pediatr Surg 2017;52(5):832-6.

14. Zaias N, Rebell G. The successful treatment of Trichophyton rubrum nail bed (distal subungual) onychomycosis with intermittent pulse-dosed terbinafine. Arch Dermatol 2004;140(6):691-5. doi: 10.1001/archderm.140.6.691.

15. Camurcu Y, Sofu H, Issin A, Kockara N, Saygili H. Operative treatment of the ingrown toenail with a less-invasive technique: Flashback to the original Winograd technique. Foot Ankle Spec 2018;11(2):138-41. doi: 10.1177/1938640017713615.

16. Chapeskie H, Kovac JR. Soft-tissue nail-fold excision: a definitive treatment for ingrown toenails. Can J Surg 2010;53(4):282-6.

17. Chapeskie H. Ingrown toenail or overgrown toe skin?: Alternative treatment for onychocryptosis. Can Fam Physician 2008;54(11):1561-2.

18. Vandenbos K, Bowers W. Ingrowing toenail: a result of weight bearing on soft tissue. U S Armed Forces Med J 1959;10:1168-73. 